\title{
ANALISIS MOTIVASI BETERNAK SAPI POTONG BAGI PETERNAK LOKAL DAN TRANSMIGRAN SERTA PENGARUHNYA TERHADAP PENDAPATAN DI KECAMATAN KAIRATU, KABUPATEN SERAM BAGIAN BARAT
}

\section{BEEF CATTLE FARMING MOTIVATION OF LOCAL AND TRANSMIGRANT FARMERS AND ITS EFFECT ON THE INCOME AT KAIRATU DISTRICT, SERAM BAGIAN BARAT REGENCY}

\author{
Christian Manase Luanmase*, Sudi Nurtini, dan F. Trisakti Haryadi \\ Fakultas Peternakan, Universitas Gadjah Mada, Jl. Fauna No. 3, Bulaksumur, Yogyakarta, 55281
}

\section{INTISARI}

Penelitian ini dilaksanakan di Kecamatan Kairatu, Kabupaten Seram Bagian Barat, dari bulan Juli sampai dengan September 2008. Materi yang digunakan dalam penelitian ini adalah 96 responden peternak lokal dan peternak transmigran dengan alat bantu kuesioner. Penentuan lokasi sampel sebanyak 4 desa, yaitu 2 desa penduduk lokal dan 2 desa penduduk transmigran secara purposive sampling, sedangkan jumlah 96 respoden dibagi atas 49 respoden peternak lokal dan 47 responden peternak transmigran secara convenience sampling. Tujuan penelitian yaitu: 1) mengetahui perbedaan motivasi dan karakteristik antara peternak lokal dan transmigran, 2) mengetahui pengaruh karakteristik peternak lokal dan transmigran terhadap motivasi, 3) mengetahui pengaruh karakteristik peternak lokal dan transmigran terhadap pendapatan, dan 4) mengetahui hubungan motivasi beternak terhadap pendapatan. Variabel yang di ukur dalam penelitian ini adalah motivasi beternak, karakteristik peternak dan pendapatan. Data dikumpulkan, dianalisis dengan bantuan komputer menggunakan Software SPSS 17 untuk menghitung tingkat motivasi beternak, karakteristik peternak dan pendapatan. Hasil penelitian menunjukkan bahwa karakteristik yang berbeda signifikan antara peternak lokal dan transmigran adalah umur peternak $(\mathrm{P}<0,01)$, tingkat pendidikan $(\mathrm{P}<0,01)$, keberanian mengambil resiko $(\mathrm{P}<0,10)$, dan curahan waktu kerja $(\mathrm{P}<0,05)$. Karakteristik yang berpengaruh signifikan terhadap motivasi adalah pengalaman peternak $(\mathrm{P}<0,05)$, jumlah tanggungan keluarga $(\mathrm{P}<0,05)$, luas lahan pertanian $(\mathrm{P}<0,10)$, dan dummy peternak $(\mathrm{P}<0,01)$. Karakteristik yang berpengaruh signifikan terhadap pendapatan adalah umur peternak $(\mathrm{P}<0,05)$, tingkat pendidikan $(\mathrm{P}<0,05)$, pengalaman peternak $(\mathrm{P}<0,10)$, kepemilikan ternak sapi $(\mathrm{P}<0,05)$ dan dummy peternak $(\mathrm{P}<0,05)$. Motivasi peternak transmigran berhubungan positif dengan pendapatan $(\mathrm{P}<0,10)$

(Kata kunci: Motivasi beternak, Karakteristik peternak, Peternak lokal, Peternak transmigran, Motif ekonomi, Motif non ekonomi, Pendapatan)

\section{ABSTRACT}

The study was conducted in Kairatu District, Seram Bagian Barat Regency district from July to September 2008. Materials used in this study were 96 respondents of local and transmigrant cattle beef farmers with questionnaires. The samples were drawn from 4 villages, consisting of 2 villages of local peoples and 2 villages of transmigrants using purposive sampling technique, while the 97 respondents consisted of 49 local and 47 transmigrant beef cattle farmers who were drawn using convenience sampling technique. The objectives of the study: 1) to find out the difference in the motivation and the characteristics of the local and the transmigrant farmers, 2) to investigate the impact of characteristics of the local and the transmigrant farmers on their motivation, 3) to investigate the impact of the characteristics of the local and the transmigrant farmers on their income, and 4) to investigate the correlation between breeding motivation and income. The variables measured in this study were breeding motivation, farmers' characteristics and income. The data were collected and analyzed using software SPSS 17 to measure the breeding motivation level, the farmers' characteristics and income. The results showed that the significant differences of characteristics between the local and the transmigrant farmers were age $(P<0.01)$, education level $(P<0.01)$, the braveness in risk taking $(P<0.10)$, and working hours $(P<0.05)$. The characteristics that had significant impact on the motivation were farming experience $(P<0.05)$, number of dependants $(P<0.05)$, width of agricultural land $(P<0.10)$, and farmers' dummy $(P<0.01)$. The characteristics that had significant impact on income were age $(P<0.05)$, education level $(P<0.05)$, farming experience $(P<0.10)$, cattle beef ownership $(P<0.05)$, and farmers's dummy $(P<0.05)$. The motivation of transmigrant farmers have positive relations to the income $(P<0.10)$.

(Key words: Breeding motivation, Farmers characteristics, Local farmers, Transmigrant farmers, Economic motif, Non-economic motif, Income)

\footnotetext{
* Korespondensi (corresponding author):

Telp.+62 8139229 6910, E-mail: tyan_amq@yahoo.com
} 


\section{Pendahuluan}

Sub-sektor peternakan merupakan rangkaian kegiatan yang berkesinambungan untuk mengembangkan kemampuan masyarakat petani peternak agar mampu melaksanakan usaha beternak sapi potong secara mandiri. Sub-sektor peternakan di Maluku khususnya Kecamatan Kairatu ditujukan bagi peternak lokal dan transmigran dalam upaya peningkatan produksi ternak sapi potong yang sekaligus meningkatkan pendapatan dan kesejahteraan, memenuhi kebutuhan gizi masyarakat, menciptakan kesempatan kerja dan kesempatan berusaha, mendorong motivasi peternak lokal dan transmigran dalam kegiatan beternak sapi potong.

Menurut data statistik Badan Pusat Statistik Maluku (2009) bahwa Kecamatan Kairatu, Kabupaten Seram Bagian Barat memiliki penduduk peternak lokal dan penduduk peternak transmigran. Peternak lokal adalah mereka yang berasal dari Pulau Seram dan sudah bertahun-tahun menempati wilayah tersebut, sedangkan peternak transmigran adalah mereka yang di transmigrasi dari Pulau Jawa dan belum lama menempati Kecamatan Kairatu.

Kecamatan Kairatu, Kabupaten Seram Bagian Barat merupakan salah satu wilayah penerimaan transmigrasi. Keberadaan transmigran di Kecamatan Kairatu masih dipandang positif sebagai salah satu pendekatan untuk mencapai tujuan kesejahteraan, pemerataan pembangunan daerah, perluasan kesempatan kerja, sedangkan kebijakan transmigrasi diarahkan pada tiga hal pokok yaitu: 1) penanggulangan kemiskinan yang disebabkan oleh ketidakberdayaan penduduk untuk memperoleh tempat tinggal yang layak, 2) memberi peluang berusaha dalam kesempatan kerja, 3) memfasilitasi pemerintah daerah dan masyarakat untuk melaksanakan perpindahan penduduk.

Secara umum peternak lokal lebih mengenal situasi dan kondisi sumber daya alam sekitarnya. Pengetahuan terhadap sumber daya alam ini memacu harapan untuk beternak sapi potong, sedangkan peternak transmigran belum mengenal lokasi, namun memiliki harapan sebagaimana peternak lokal. Teori mengungkap harapan yang dikemukakan oleh Asnawi (2007) bahwa seseorang menginginkan hal-hal yang baik sehingga daya penggerak yang memotivasi semangat seseorang terkandung dari harapan yang akan diperoleh di masa depan.

Peternak transmigran biasanya bertransmigrasi ke suatu tempat karena adanya motivasi atau keinginan demi mendapatkan kehidupan yang layak. Kemampuan untuk memotivasi diri sendiri terhadap lingkungan baru menunjukkan kematangan mental dalam mengambil resiko meninggalkan daerah asal. Handoko (2006) menyatakan bahwa motivasi terhadap lingkungan yang baru memacu sikap dan mental seseorang untuk memanfaatkan sumberdaya yang ada secara efektif. Suparno (1994) menyatakan bahwa tujuan transmigrasi diasumsikan sebagai kawasan akomodatif menerima kehadiran transmigran yang datang dari daerah lain. Tujuan transmigrasi berfungsi sebagai the hope land bagi kaum transmigran. Selanjutnya Asnawi (2007) menambahkan bahwa selain motivasi, maka perlu adanya dorongan dari faktor internal dan faktor eksternal yang membuat seseorang memutuskan untuk berpindah ke daerah tujuan dengan suatu harapan.

Hasil penelitian dari peneliti-peneliti terdahulu melaporkan bahwa motivasi dan faktor internal maupun eksternal seperti umur, tingkat pendidikan, pengalaman beternak, jumlah tanggungan keluarga, keberanian mengamil resiko, kepemilikan ternak dan luas lahan turut berpengaruh pada maju mundurnya usaha beternak sapi potong.

Sehubungan dari awal penjelasan di atas maka penulis merasa perlu mengangkat permasalahan ini untuk diteliti dan dikaji secara mendasar tentang motivasi beternak sapi potong bagi peternak lokal dan transmigran serta pengaruhnya terhadap pendapatan di Kecamatan Kairatu, Kabupaten Seram Bagian Barat.

Permasalahan yang diangkat dalam penelitian ini adalah 1) adakah perbedaan motivasi beternak dan karakteristik antara peternak lokal dan transmigran?, 2) adakah perbedaan karakteristik peternak lokal dan transmigran terhadap motivasi?, 3) adakah perbedaan karakteristik peternak lokal dan transmigran terhadap pendapatan?, dan 4) adakah hubungan antara motivasi beternak dengan pendapatan?.

Penelitian ini bertujuan untuk: 1) mengetahui perbedaan motivasi beternak dan karakteristik antara peternak lokal dan transmigran, 2) mengetahui pengaruh karakteristik peternak lokal dan transmigran terhadap motivasi, 3) mengetahui pengaruh karakteristik peternak lokal dan transmigran terhadap pendapatan, dan 4) mengetahui hubungan motivasi beternak dengan pendapatan.

Manfaat yang diharapkan dari penelitian ini, antara lain: 1) Diharapkan bagi petani/peternak di Kecamatan Kairatu, Kabupaten Seram Bagian Barat agar lebih meningkatkan motivasi beternak sapi potong, 2) Hasil penelitian ini dapat dipakai sebagai bahan pertimbangan bagi pemerintah daerah dalam menetapkan kebijakan pembangunan sub-sektor peternakan yang berhubungan dengan usaha pemeliharaan ternak sapi potong. 


\section{Materi dan Metode}

\section{Materi penelitian}

Penelitian ini dilaksanakan di Kecamatan Kairatu, Kabupaten Seram Bagian Barat, yang dilaksanakan awal bulan Juli sampai dengan September 2008. Materi yang digunakan dalam penelitian ini adalah peternak lokal dan transmigran sebanyak 96 responden (49 peternak lokal dan 47 transmigran).

\section{Metode penelitian}

Metode yang digunakan dalam penelitian ini meliputi dua tahap. Tahap pertama adalah tahap persiapan dan tahap kedua adalah tahap pelaksanaan. Tahap persiapan dilakukan untuk meninjau lapangan guna memperoleh gambaran tentang daerah penelitian untuk menentukan sampel. Tahap pelaksanaan dilakukan guna mengumpulkan data primer dan data sekunder.

Penelitian ini dilakukan di empat desa yang didalamnya terdapat dua desa penduduk lokal dan dua desa penduduk transmigran. Desa penduduk lokal yaitu Desa Hatusua dan Desa Lohiatala, sedangkan Desa penduduk transmigran yaitu Desa Waihatu dan Desa Gemba. Pemilihan lokasi ini dilakukan secara purposive sampling dengan pertimbangan bahwa daerah tersebut mempunyai populasi sapi potong paling banyak dibanding dengan desa lain. Responden diambil secara convenience sampling yaitu sebanyak 49 peternak lokal dan 47 peternak transmigran. Empat puluh sembilan peternak lokal diambil dari 25 peternak asal Desa Hatusua dan 24 peternak asal Desa Lohiatala, sedangkan 47 peternak transmigran diambil dari 25 peternak asal Desa Waihatu dan 22 peternak asal Desa Gemba.

\section{Pengambilan data}

Pengambilan data dilaksanakan dengan metode survei. Data yang digunakan dalam penelitian ini adalah data primer dan data sekunder. Data primer diperoleh dari hasil wawancara dengan peternak sampel untuk mengetahui karakteristik responden, motivasi (motif ekonomi dan motif non ekonomi), serta biaya dan penerimaan. Data sekunder diperoleh dari pihak-pihak yang terkait dalam penelitian ini menyangkut keadaan lokasi dan populasi ternak. Data yang dikumpulkan dalam penelitian ini adalah: umur peternak, tingkat pendidikan, pengalaman peternak, keberanian mengambil resiko, curahan waktu kerja, jumlah tanggungan keluarga, motivasi (motif ekonomi, motif non ekonomi) dan pendapatan. Alat yang digunakan dalam penelitian ini adalah kuesioner. Kuesioner yang digunakan berupa daftar pertanyaan untuk mengetahui motivasi beternak, karakteristik peternak dan pendapatan.

\section{Uji validitas dan reliabilitas kuesioner}

Uji validitas alat ukur kuesioner menggunakan rumus Korelasi Product Moment Pearson berdasarkan Singarimbun dan Effendy (1995) sebagai berikut:

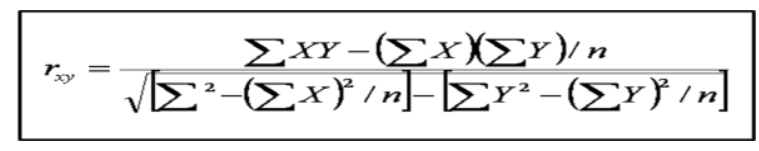

$\mathrm{r}_{\mathrm{xy}}=$ koefisien validitas $\mathrm{xy}, \mathrm{X}=$ skor masingmasing variabel, $\mathrm{Y}=$ variabel (ekonomi dan non ekonomi). Bila $r_{x y}$ hitung $>r_{\text {tabel }}(n-2 ; 5 \%)$ maka hasil pengukuran valid. Hasil uji statistik kuesioner valid pada kuesioner motivasi sebanyak 15 butir pertanyaan, diantaranya 9 pertanyaan motif ekonomi dan 6 pertanyaan motif non ekonomi $(\mathrm{P}<0,05)$.

Untuk mengetahui koefisien reliabilitas instrumen (Cronbach) dapat menggunakan rumus sebagai berikut:

$r_{11}=\left(\frac{k}{k-1}\right)\left(1-\frac{\sum \sigma_{b}^{2}}{\sigma_{1}^{2}}\right)$

$\mathrm{r}_{11}=$ reliabilitas instrument, $\mathrm{k}=$ banyak butir pertanyaan, $\sigma_{1}^{2}=$ varian total, $\sum \sigma_{1}^{2}=$ jumlah varian butir, $1=$ konstanta. Hasil uji statistik reliabilitas Cronbach's Alpha sebesar 0,917 untuk motif ekonomi dan 0,876 untuk motif non ekonomi. Ini berarti bahwa $r$ hitung lebih besar dari $r_{\text {tabel }}$ maka kuesioner ini dapat digunakan dalam penelitian. Santoso dan Ashari (2005) cit. Marnidati (2007) menyatakan bahwa suatu kuesioner dikatakan reliabel jika nilai Cronbach Alpha lebih besar dari 0,60 sehingga kuesioner layak digunakan dalam penelitian.

\section{Pengukuran tingkat motivasi}

Mengetahui tingkat motivasi, perlu ditentukan skor tinggi, skor terendah dan skor titik tengah. Skor maksimum diperoleh dari perkalian antara skor tinggi (5) dengan jumlah item pertanyaan dari masing-masing indikator motivasi. Skor minimum diperoleh dari perkalian antara skor terendah (1) dengan jumlah item pertanyaan. Pengukuran tingkat motivasi dibagi atas dua indikator yaitu: motif ekonomi dan motif non ekonomi. Tingkat motivasi diukur menggunakan 15 butir pertanyaan, diantaranya 9 pertanyaan untuk mengukur motif ekonomi dan 6 pertanyaan untuk mengukur motif non ekonomi.

Hasil pengukuran tingkat motivasi menunjukkan bahwa terdapat total skor maksimum motivasi sebesar 75 dan skor minimum sebesar 15. Motivasi dengan kategori rendah antara 15 sampai 44 dan 
kategori tinggi antara 45 sampai 75. Selanjutnya motif ekonomi untuk kategori rendah antara 9 sampai 26 dan kategori tinggi antara 27 sampai 45 , sedangkan motif non ekonomi kategori rendah antara 6 sampai 17 dan kategori tinggi antara 18 sampai 30 .

\section{Analisis data}

Analisis deskriptif dilakukan untuk mengetahui perbedaan karakteristik peternak dan motivasi beternak sapi potong antara peternak lokal dan transmigran. Untuk mengetahui faktor-faktor karakteristik peternak lokal dan transmigran terhadap motivasi beternak, dianalisis dengan persamaan regresi berganda menurut Gudjarati (2003) dengan persamaan regresi sebagai berikut:

$$
\begin{aligned}
\mathrm{M}= & \mathrm{a}+\beta_{1} \mathrm{X}_{1}+\beta_{2} \mathrm{X}_{2}+\beta_{3} \mathrm{X}_{3}+\beta_{4} \mathrm{X}_{4}+\beta_{5} \mathrm{X}_{5}+\beta_{6} \mathrm{X}_{6}+ \\
& \beta_{7} \mathrm{X}_{7}+\beta_{8} \mathrm{X}_{8}+\mathrm{D}+\mathrm{e} .
\end{aligned}
$$

(M) motivasi, (A) konstanta, $\left(\beta_{1,2}, \beta_{3}\right)$ koefisien regresi, $\left(\mathrm{X}_{1}\right)$ umur peternak (tahun), $\left(\mathrm{X}_{2}\right)$ tingkat pendidikan (tahun), $\left(\mathrm{X}_{3}\right)$ pengalaman peternak (tahun), $\left(\mathrm{X}_{4}\right)$ keberanian mengambil risiko (skor), $\left(\mathrm{X}_{5}\right)$ curahan waktu kerja $(\mathrm{HOK}),\left(\mathrm{X}_{6}\right)$ jumlah tanggungan keluarga (orang), $\left(\mathrm{X}_{7}\right)$ kepemilikan ternak sapi (UT) $\left(\mathrm{X}_{8}\right)$ ketersediaan lahan pertanian $\left(\mathrm{m}^{2}\right)$, (D) dummy variabel untuk jenis peternak lokal adalah 0 dan transmigran adalah 1 , (e) error.

Untuk mengetahui faktor-faktor karakteristik peternak lokal dan transmigran terhadap pendapatan, dianalisis menurut Gudjarati (2003) dengan persamaan regresi sebagai berikut:

$$
\begin{aligned}
\mathrm{M}= & \mathrm{a}+\beta_{1} \mathrm{X}_{1}+\beta_{2} \mathrm{X}_{2}+\beta_{3} \mathrm{X}_{3}+\beta_{4} \mathrm{X}_{4}+\beta_{5} \mathrm{X}_{5}+\beta_{6} \mathrm{X}_{6}+ \\
& \beta_{7} \mathrm{X}_{7}+\beta_{8} \mathrm{X}_{8}+\mathrm{D}+\mathrm{e} .
\end{aligned}
$$

(M) motivasi, (A) konstanta, $\left(\beta_{1,2}, \beta_{3}\right)$ koefisien regresi, $\left(\mathrm{X}_{1}\right)$ umur peternak (tahun), $\left(\mathrm{X}_{2}\right)$ tingkat pendidikan (tahun), $\left(\mathrm{X}_{3}\right)$ pengalaman peternak (tahun), $\left(\mathrm{X}_{4}\right)$ keberanian mengambil risiko (skor), $\left(\mathrm{X}_{5}\right)$ curahan waktu kerja $(\mathrm{HOK}),\left(\mathrm{X}_{6}\right)$ jumlah tanggungan keluarga (orang), $\left(\mathrm{X}_{7}\right)$ kepemilikan ternak sapi (UT) $\left(\mathrm{X}_{8}\right)$ ketersediaan lahan pertanian $\left(\mathrm{m}^{2}\right)$, (D) dummy variabel untuk jenis peternak lokal adalah 0 dan transmigran adalah 1 , (e) error .

Untuk mengetahui hubungan motivasi dengan pendapatan digunakan analisis Pearson Correlation menurut Mardalis (2007) sebagai berikut:

$$
r_{x y}=\frac{\sum x y-\frac{\left(\sum x\right)\left(\sum y\right)}{N}}{\sqrt{\left[\sum x^{2}-\frac{\left(\sum x\right)^{2}}{N}\right]\left[\sum y^{2}-\frac{\left(\sum y\right)^{2}}{N}\right]}}
$$

$\mathrm{r}_{x y}=$ koefisien korelasi Pearson, $y=$ variabel (motivasi dan pendapatan), $\sum_{\mathrm{xy}}=$ perbedaan ranking antara dua variabel, $N=$ jumlah sampel.

\section{Hasil dan Pembahasan}

\section{Gambaran umum lokasi penelitian}

Kecamatan Kairatu, Kabupaten Seram Bagian Barat terletak di Pulau Seram dan terdapat di Propinsi Maluku. Secara astronomi letak wilayah Kecamatan Kairatu berada pada posisi $6^{0}$ sampai $7^{0}$ Lintang Selatan dan $55^{\circ}$ sampai $127^{\circ}$ Bujur Timur sedangkan secara geografis memiliki batas-batas wilayah sebagai berikut: sebelah utara dengan Laut Seram, sebelah selatan dengan Laut Banda, sebelah timur dengan Kabupaten Maluku Tengah, sebelah barat dengan Laut Buru (BPS Maluku, 2009).

Jenis ternak yang dipelihara di Kecamatan Kairatu, Kabupaten Seram Bagian Barat adalah ternak sapi potong, babi, kambing dan kerbau. Desa yang memiliki jumlah ternak sapi potong terbanyak berturut-turut adalah Desa Gemba sebanyak 1.284 ekor, Desa Waihatu sebanyak 1.217 ekor, Desa Lohiatala sebanyak 1.099 ekor dan Desa Hatusua sebanyak 1.062 ekor (BPS Maluku, 2009).

\section{Pola pemeliharaan ternak sapi potong oleh peternak lokal dan transmigran}

Secara umum peternak lokal masih berpola pada pemeliharaan sapi potong tanpa menggunakan kandang. Ternak dilepas dan ikat pindah di areal rumput atau sering ditambatkan di areal perkebunan. Maitimu (2000) mengatakan bahwa pola pemeliharaan sapi tanpa kandang dan hanya diikat lepas menyebabkan ternak mudah terserang penyakit dan lambat dalam pengobatan ternak.

Keseluruhan penduduk transmigran masih terus menekuni usaha pemeliharaan sapi potong dengan menggunakan kandang sebagai tempat perlindungan bagi ternak. Konstruksi kandang sangat sederhana dengan menggunakan sisa potongan kayu, lantai dasar hanya dari tanah dan atapnya terbuat dari sirap. Pentingnya kandang bagi ternak agar terhindar dari ancaman lingkungan yang merugikan seperti terik matahari, tiupan angin, hujan dan lain sebagainya. Kegunaan kandang juga untuk mempermudah pengontrolan terhadap ternak, menghindarkan ternak berkeliaran di sembarang tempat dan dari gangguan binatang buas dan pencuri. Letak bangunan kandang berdekatan dengan rumah tempat tinggal mereka dan jarak kandang dengan rumah berkisar antara 10 sampai $12 \mathrm{~m}$, sedangkan luas kandang ternak adalah $3 \times 6 \mathrm{~m}$ dan luas kandang pakan ternak adalah $1 \times 2 \mathrm{~m}$.

Dijelaskan pula bahwa peternak transmigran sering melakukan pola semi intensif yaitu lepas, ikat dan dikandangkan dan telah ditekuni secara turun- 
temurun dengan menggembalakan ternak dipadang rumput, mencari pakan untuk ternak, mengambil dan memberi minum ternak, membersihkan ternak serta mengandangkan ternak, sedangkan peternak lokal hanya mengumbar dan mengikat ternak sapi pada areal penggembalaan.

\section{Perbedaan karakteristik antara peternak lokal dan transmigran}

Keberhasilan usaha peternakan tidak terlepas dari faktor umur, tingkat pendidikan, pengalaman peternak, keberanian mengambil resiko, curahan waktu kerja, jumlah tanggungan keluarga, kepemilikan ternak sapi dan ketersediaan lahan pertanian hijauan makanan ternak. Analisis deskriptif untuk mengetahui perbedaan karakteristik peternak lokal dan transmigran dengan bantuan komputer menggunakan SPSS 17. Rerata perbedaan karakteristik antara peternak lokal dan transmigran tersaji pada Tabel 1 .

Hasil pada Tabel 1 menunjukkan bahwa umur berbeda sangat signifikan $(\mathrm{P}<0,01)$ antara peternak lokal dan peternak transmigran. Umur peternak lokal lebih tua dibanding peternak transmigran. Meski perbedaan sangat nyata, tetapi seluruh responden dikategorikan dalam umur produktif. Rerata umur peternak lokal 49,83 tahun dan peternak transmigran 48,46 tahun. Tarmidi (1992) mengatakan bahwa di kelompok usia seperti itu merupakan kelompok usia produktif dengan kemampuan kerja dan berpikir yang baik.

Tingkat pendidikan berbeda sangat signifikan $(\mathrm{P}<0,01)$ antara peternak lokal dan transmigran. Pendidikan formal peternak transmigran tergolong rendah dibanding peternak lokal. Rerata tingkat pendidikan peternak lokal 10,14 tahun dan peternak transmigran 8,42 tahun.
Sarwono (2001) menyatakan bahwa tingkat pendidikan yang baik akan cenderung mudah untuk menerima informasi baru dalam teknik beternak yang baik, selain memberikan tanggapan positif pada setiap kemajuan usaha beternak juga lebih matang untuk memecahkan setiap permasalahan yang dihadapinya. Pernyataan di atas bertolak belakang dengan hasil penelitian ini, karena ditemui rendah pendidikan peternak transmigran, tetapi usaha ternak sapi potong lebih maju dibanding peternak lokal. Hal ini ada kaitan dengan pengalaman peternak transmigran sewaktu terlibat dalam kelompok usaha tani-ternak. Sewaktu berada dalam kelompok usaha tani-ternak, mereka sering mendapat pembinaan dari instansi terkait (Dinas Peternakan). Pembinaan inilah yang membuat pengetahuan transmigran bertambah, yang pada akhirnya usaha tani-ternak lebih berhasil dibanding peternak lokal.

Pengalaman tidak berbeda signifikan antara peternak lokal dan transmigran. Meski tidak berbeda nyata, namun peternak transmigran dan lokal mempunyai pengalaman yang cukup lama dengan usaha sapi potong. Rerata pengalaman peternak transmigran sebesar 10,69 tahun dan peternak lokal 6,29 tahun.

Keberanian mengambil resiko berbeda signifikan $(\mathrm{P}<0,10)$ antara peternak lokal dan transmigran. Peternak transmigran lebih berani mengambil resiko dibanding peternak lokal. Rerata skor keberanian peternak transmigran sebesar 6,55 dan peternak lokal 3,85. Hasil penelitian mengenai keberanian mengambil resiko menyangkut penerapan teknologi yang mengungkap pertanyaan tentang respon peternak apabila ada penyampaian teknologi mengenai Inseminasi Buatan (IB), pencegahan penyakit, pengobatan dan bantuan kredit,

Tabel 1. Rerata perbedaan karakteristik antara peternak lokal dan transmigran (mean of characteristic differences local farmers and transmigrant)

\begin{tabular}{|c|c|c|c|}
\hline \multirow[b]{2}{*}{ Karakteristik (characteristics) } & \multicolumn{2}{|c|}{ Jenis peternak (farmers type) } & \multirow[b]{2}{*}{$\begin{array}{l}\text { Signifikan } \\
\text { (significant) }\end{array}$} \\
\hline & $\begin{array}{l}\text { Lokal } \\
(\text { local })\end{array}$ & $\begin{array}{l}\text { Transmigran } \\
\text { (transmigrant) }\end{array}$ & \\
\hline Umur peternak (tahun) (farmers age (year)) & 49,83 & 48,46 & $0,000 * * *$ \\
\hline Pendidikan (tahun) (education (year)) & 10,14 & 8,42 & $0,000 * * *$ \\
\hline Pengalaman peternak (tahun) (farmers experiences (year)) & 6,29 & 10,69 & $0,687^{\mathrm{ns}}$ \\
\hline Keberanian mengambil resiko (skor) (risk taking (score)) & 3,85 & 6,55 & $0,060^{*}$ \\
\hline Curahan waktu kerja (HOK) (working hour (HOK)) & 3,59 & 4 & $0,046 * *$ \\
\hline $\begin{array}{l}\text { Jumlah tanggungan keluarga (orang) (the number of } \\
\text { dependents family (person)) }\end{array}$ & 2,00 & 1,65 & $0,801^{\mathrm{ns}}$ \\
\hline Kepemilikan ternak sapi (UT) (cattle ownership (UT)) & 2,24 & 4,07 & $0,485^{\text {ns }}$ \\
\hline Luas lahan HMT $\left(\mathrm{m}^{2}\right)$ (area of animal feed plant $\left(\mathrm{m}^{2}\right)$ ) & $1.580,81$ & $1.677,87$ & $0,833^{\text {ns }}$ \\
\hline
\end{tabular}


bagaimana merespon informasi tersebut. Peternak transmigran menyatakan langsung menerapkan sebesar 55,31\% dan lokal sebesar 6,12\%. Hal ini berarti di atas $50 \%$ peternak transmigran merespon penyampaian teknologi dibanding peternak lokal. Terdapat juga pernyataan lain oleh peternak lokal, yaitu melihat cara penerapan dari orang lain sebesar 93,88\%. Ini berarti sebagian besar peternak lokal masih lemah dalam menerima informasi. Mereka harus melihat cara-cara menggunakan teknologi dari peternak lain, baru bisa menerapkannya dibanding peternak transmigran yang langsung menerima informasi sekaligus menerapkan teknologi.

Selanjutnya keseluruhan peternak transmigran menyatakan bahwa mereka akan mengembangkan usaha ternak sapi potong, sedangkan peternak lokal menjawab akan disimpan sebagai tabungan. Hal ini menunjukkan bahwa peternak transmigran lebih cenderung menjalankan usaha ternak sapi potong dan ingin membesarkan usaha tersebut bila memiliki modal sendiri, sedangkan peternak lokal kalau bermodal sendiri akan disimpan sebagai sumber tabungan $(81,63 \%)$. Pernyataan lain dari peternak transmigran bahwa mereka lebih mudah beternak sapi potong dibanding usaha ternak lain. Hal ini disebabkan karena mereka sudah terbiasa dengan usaha sapi sejak dulu dan sapi inilah yang sering mengolah lahan pertanian padi, artinya dari beternak sapi memberikan keuntungan bagi lahan pertanian transmigran, sedangkan peternak lokal menyatakan kalau usaha ternak sapi tersebut hanya biasa saja $(83,67 \%)$. Mereka menganggap bahwa usaha beternak sapi potong hanya sebagai usaha sampingan yang sewaktu-waktu dapat membantu kebutuhan ekonomi keluarga yang mendesak. Penjelasan lain, karena dianggap biasa-biasa saja terhadap usaha sapi potong maka ternak ditelantarkan dipadang penggembalaan sepanjang hari tanpa ada pengawasan.

Curahan waktu kerja berbeda signifikan $(\mathrm{P}<0,05)$ antara peternak lokal dan transmigran. Jam kerja peternak transmigran lebih lama dibanding peternak lokal. Rerata jam kerja peternak lokal sebanyak 3,59 jam per hari atau sekitar 0,44 HOK, sedangkan peternak transmigran sebanyak 4 jam per hari atau sekitar 0,5 HOK. Hasil uraian di atas tidak jauh berbeda dengan hasil penelitian Siregar (2009) bahwa curahan waktu kerja untuk mengurus ternaknya adalah sebesar 3,15 jam per hari atau sekitar 0,39 HOK.

Tanggungan keluarga tidak berbeda signifikan antara peternak lokal dan transmigran. Rerata tanggungan peternak transmigran sebanyak 1,63 orang dan peternak lokal sebanyak 2,00 orang. Bossard dan Boll cit. Ahmadi (2003) menyatakan bahwa masyarakat itu mula-mula terdiri dari small family (keluarga kecil) yaitu suatu keluarga yang terdiri dari ayah, ibu, dan anaknya paling banyak 2 atau 3 orang anak. Pada keluarga kecil ini biasanya yang menjadi tanggungan hidup adalah ibu dan anak-anak.

Kepemilikan ternak sapi tidak berbeda signifikan antara peternak lokal dan transmigran. Rerata untuk peternak lokal sebesar 3,10 unit ternak dan peternak transmigran sebesar 5,63 unit ternak.

Ketersediaan lahan pertanian tidak berbeda signifikan antara peternak lokal dan transmigran. Peternak lokal dan transmigran mempunyai lahan hijauan untuk makanan ternak. Rerata lahan hijauan peternak transmigran sebesar $1.677,87 \mathrm{~m}^{2}$ dan peternak lokal 1.519,59 $\mathrm{m}^{2}$.

\section{Motivasi beternak sapi potong}

Motivasi beternak sapi potong didasari oleh motif ekonomi dan motif non ekonomi. Hasil penelitian menunjukkan bahwa keseluruhan peternak transmigran memiliki motif dan motivasi yang tergolong tinggi. Meski peternak lokal memiliki motif dan motivasi tergolong tinggi, tetapi beberapa peternak mempunyai motif dan motivasi rendah, diantaranya motif ekonomi rendah $6,12 \%$ dan tinggi sebesar 93,88\%. Motif non ekonomi rendah $8,16 \%$ dan tinggi sebesar $91,83 \%$, sedangkan motivasi rendah $6,12 \%$ dan tinggi sebesar 93,88\%.

Dijelaskan pula bahwa peternak transmigran sangat setuju atas pernyataan motif ekonomi sebanyak $97,87 \%$ dan setuju $2,13 \%$. Mereka berpendapat bahwa usaha beternak sapi potong sangatlah mudah untuk mengembalikan modal, namun terdapat juga jawaban ragu-ragu oleh peternak transmigran sebanyak $97,87 \%$. Mereka berpendapat kalau usaha beternak sapi potong sangat menguntungkan karena input yang dikeluarkan sangat kecil. Selanjutnya peternak transmigran sangat setuju untuk motif ekonomi sebanyak $97,87 \%$ dan setuju 2,13\%. Mereka berpendapat bahwa tenaga kerja keluarga sangat dibutuhkan untuk mengelola usaha ternak sapi potong.

Peternak lokal menyatakan sangat setuju atas pernyataan motif ekonomi sebanyak $24,49 \%$ dan setuju $75,51 \%$. Mereka berpendapat bahwa kalau usaha beternak sapi potong sangatlah mudah untuk mengembalikan modal, namun ada juga empat jawaban ragu-ragu oleh peternak lokal, diantaranya 85,$71 ; 83,67$; 87,76; dan 91,82\%. Mereka berpendapat bahwa usaha beternak sapi potong sangat menguntungkan karena input yang dikeluarkan sangat kecil dibanding usaha lain, kemudian dengan beternak sapi potong maka pendapatan keluarga akan meningkat. Selanjutnya pemeliharaan sapi potong dapat memberikan masukan modal yang 
cepat, kemudian merasa puas dengan bertambahnya pendapatan dari usaha beternak sapi potong.

\section{Pendapatan peternak lokal dan transmigran}

Total pendapatan diperoleh dari total penerimaan dikurangi total biaya. Soekartawi et al. (1986) menyatakan bahwa selisih antara pendapatan kotor usaha tani dengan pengeluaran total usahatani disebut pendapatan bersih (net farm income). Perhitungan total biaya berdasarkan biaya yang dikeluarkan selama satu tahun pemeliharaan dan penerimaan diperoleh dari total kenaikan nilai ternak ditambah dengan total nilai pedet. Hasil penelitian menunjukkan bahwa rerata pendapatan peternak transmigran sebesar Rp. 7.062.990,63 per tahun per unit ternak dan peternak lokal sebesar Rp. 4.410.501,00 per tahun per unit ternak. Rerata penerimaan peternak transmigran sebesar Rp. 8.193.464,05 per tahun per unit ternak dan peternak lokal sebesar Rp 4.806.120,80 per tahun per unit ternak. Biaya peternak lokal sebesar Rp. 395.619,80 per tahun per unit ternak dan transmigran sebesar Rp. 1.130.473,43.

Besarnya penerimaan nilai pedet oleh peternak transmigran disebabkan karena adanya program pengembangan sapi melalui IB. Hal tersebut adalah satu jalan dalam peningkatan produktivitas sapi. Siregar (1997) menyatakan bahwa pengembangan sapi melalui IB menunjukkan adanya peningkatan produktivitas sapi di Indonesia. Tiga alasan pokok memilih program IB yaitu: 1) IB adalah cara yang paling murah dalam meningkatkan mutu genetik sapi, 2) IB adalah cara yang paling cepat dalam transformasi dan konfigurasi genetik populasi ternak, dan 3) alternatif murah dan cepat dari program ini dapat diterapkan dalam skala massal.
Peternak lokal masih mengawinkan ternak secara alami dengan jarak kelahiran yang begitu lama, akhirnya produktivitas ternak bibit sapi potong rendah.

\section{Pengaruh karakteristik antara peternak lokal dan transmigran terhadap motivasi}

Variabel yang diamati dalam penelitian ini adalah umur peternak, tingkat pendidikan, pengalaman peternak, keberanian mengambil resiko, curahan waktu kerja, jumlah tanggungan keluarga, kepemilikan ternak (UT) dan luas lahan hijauan makanan ternak. Hasil analisis regresi pengaruh karakteristik peternak terhadap motivasi beternak tersaji pada Tabel 2 .

Hasil analisis regresi pada Tabel 2 menunjukkan bahwa berdasarkan uji $\mathrm{F}$ secara bersama-sama variabel bebas yang diamati berpengaruh nyata terhadap motivasi beternak $(\mathrm{P}<0,05)$. Nilai koefisien $R^{2}$ sebesar 0,864 , nilai ini sebesar $86,4 \%$ adalah motivasi yang dapat dijelaskan berdasarkan variabel umur peternak, tingkat pendidikan, pengalaman peternak, keberanian mengambil resiko, curahan waktu kerja, jumlah tanggungan keluarga, dan luas lahan pertanian HMT, sedangkan sisa $13,6 \%$ dipengaruhi oleh variabel lain yang tidak diamati pada penelitian. Variabel yang berpengaruh signifikan terhadap motivasi beternak adalah $\left(\mathrm{X}_{6}\right)$ pengalaman peternak $(\mathrm{P}<0,05), \quad\left(\mathrm{X}_{6}\right)$ jumlah tanggungan keluarga $(\mathrm{P}<0,05),\left(\mathrm{X}_{8}\right)$ luas lahan $(\mathrm{P}<0,10)$, dan (D) dummy peternak $(\mathrm{P}<0,01)$.

Pengalaman peternak $\left(X_{3}\right)$ berpengaruh signifikan $(\mathrm{P}<0,05)$ terhadap motivasi artinya bertambah 1 tahun pengalaman peternak, motivasi meningkat sebesar 0,097. Hal ini menunjukkan bahwa semakin tinggi pengalaman peternak semakin tinggi pula motivasi, sebaliknya semakin rendah pengalaman peternak, maka semakin rendah pula motivasi

Tabel 2. Hasil analisis regresi berganda pengaruh faktor karakteristik peternak lokal dan transmigran terhadap motivasi (result of analisis regression influence of local farmers characteristic factor and transmigrant to motivation)

\begin{tabular}{|c|c|c|c|}
\hline Variabel bebas (free variable) & $\begin{array}{c}\text { Koefisien regresi } \\
\text { (regression coeficcient) }\end{array}$ & $\begin{array}{c}\text { Nilai t } \\
(\text { value } t)\end{array}$ & $\begin{array}{l}\text { Probabilitas } \\
(\text { probability) }\end{array}$ \\
\hline Umur peternak (tahun) (farmers age (year)) & -0.003 & $-0.083^{\text {ns }}$ & 0.934 \\
\hline Tingkat pendidikan (tahun) (level of education (year)) & 0.168 & $1.262^{\mathrm{ns}}$ & 0.211 \\
\hline Pengalaman peternak (tahun) (farmers experiences (year)) & 0.115 & $2.027^{* *}$ & 0.046 \\
\hline Keberanian mengambil resiko (skor) (risk taking (score)) & 0.204 & $0.512^{\mathrm{ns}}$ & 0.610 \\
\hline Curahan waktu kerja (HOK) (working hour (HOK)) & -0.324 & $-0.733^{\text {ns }}$ & 0.466 \\
\hline $\begin{array}{l}\text { Jumlah tanggungan keluarga (orang) (the number of } \\
\text { dependents family (person)) }\end{array}$ & -1.291 & $-3.140^{* * *}$ & 0.002 \\
\hline Kepemilikan ternak sapi (UT) (cattle ownership (UT)) & -0.067 & $-0.413^{\mathrm{ns}}$ & 0.681 \\
\hline Luas lahan HMT $\left(\mathrm{m}^{2}\right)\left(\right.$ area of animal feed plant $\left.\left(\mathrm{m}^{2}\right)\right)$ & 0.000 & $-1.902 *$ & 0.060 \\
\hline Dummy & 12.233 & $9.987^{* * * *}$ & 0.000 \\
\hline Konstanta (costanta) & 53.509 & $16.316^{* * *}$ & 0.000 \\
\hline
\end{tabular}


beternak. Mereka yang memiliki pengalaman beternak tinggi akan semakin meningkatkan motivasi kerja, yang pada akhirnya memperlihatkan keberhasilan dalam kegiatan usaha peternakan.

Jumlah tanggungan keluarga $\left(\mathrm{X}_{6}\right)$ berpengaruh sangat signifikan $(\mathrm{P}<0,01)$ dengan koefisien negatif, artinya bertambah satu tanggungan keluarga, motivasi berkurang sebesar 0,131. Makin banyak jumlah tanggungan keluarga semakin mengurangi motivasi beternak, atau makin sedikit jumlah tanggungan keluarga semakin meningkat motivasi beternak. Siregar (2009) menyatakan bahwa sebagian peternak kurang memiliki motivasi karena kurang gagasan/ide yang juga berbenturan dengan besarnya jumlah tangggungan.

Luas lahan HMT $\left(\mathrm{X}_{8}\right)$ berpengaruh signifikan $(\mathrm{P}<0,10)$ terhadap motivasi, artinya makin luas lahan HMT maka motivasi meningkat sebesar 0,081. Makin luas hijauan makan ternak semakin meningkatkan motivasi beternak, sebaliknya makin sempit lahan pertanian semakin rendah motivasi beternak. Hal ini menunjukkan bahwa karena adanya lahan hijauan yang luas, mendorong peternak untuk giat bekerja pada usaha sapi potong.

Dummy peternak berpengaruh sangat signifikan $(\mathrm{P}<0,01)$ terhadap motivasi, artinya peternak transmigran memilliki motivasi yang tinggi terhadap usaha sapi potong dibanding peternak lokal. Mereka yang memiliki motivasi tinggi, akan berupaya untuk bekerja maksimal pada usaha sapi potong. Hal ini menunjukkan bahwa suatu keberhasilan yang diperlihatkan peternak akan menjadi sumber inspirasi bagi peternak lain untuk lebih meningkatkan motivasi beternak. Fathoni (2004) menyatakan bahwa kekuatan motivasi timbul atas dorongan sumber daya manusia yang ada di lingkungannya.

Umur peternak $\left(\mathrm{X}_{1}\right)$ tidak berpengaruh signifikan terhadap motivasi. Hal ini diduga bahwa di usia produktif, peternak lebih banyak waktu kerja pada lahan pertanian, perkebunan dibanding waktu kerja pada usaha ternak. Alokasi waktu yang dihabiskan peternak pada usaha lain mencerminkan kurang perhatian terhadap usaha sapi potong.

Tingkat pendidikan $\left(\mathrm{X}_{2}\right)$ tidak berpengaruh signifikan terhadap motivasi. Hal ini diduga bahwa tingkat pendidikan di daerah penelitian masih tergolong rendah antara 8,40 sampai 10,14 tahun. Hal demikian akan berpengaruh pada maju mundurnya usaha beternak sapi potong. Anggorodi (1998) mengatakan bahwa umumnya peternak di pedesaan masih tergolong berpendidikan rendah dengan kemampuan terbatas. Mereka hanya mampu beternak secara tradisional akibat ketergantungan pada pendidikan mereka.
Keberanian mengambil resiko $\left(\mathrm{X}_{4}\right)$ tidak berpengaruh signifikan terhadap motivasi. Hal ini diduga karena sebagian besar peternak sapi potong belum menanggapi dan merespon penyampaian penerapan teknologi. Rumalutur (2001) menyatakan bahwa umumnya tingkat adopsi peternak di pedesaan terhadap inovasi masih tergolong rendah akibat rendah pengetahuan, pengalaman dan keterampilan.

Curahan waktu kerja $\left(\mathrm{X}_{5}\right)$ tidak berpengaruh signifikan terhadap motivasi. Hal ini diduga karena waktu yang digunakan peternak lebih banyak pada usaha pertanian. Hasil penelitian Sani (2008) menyatakan bahwa curahan waktu kerja peternak lokal dan transmigran pada usaha sapi potong lebih sedikit. Hal ini disebabkan karena usaha sapi potong hanya dijadikan sebagai usaha sambilan dan tradisional.

Kepemilikan ternak sapi $\left(\mathrm{X}_{7}\right)$ tidak berpengaruh signifikan terhadap motivasi beternak. Hal ini diduga karena kepemilikan usaha ternak sapi di daerah penelitian masih diusahakan dalam skala kecil antara 2,24 sampai 4,07 unit ternak per peternak. Soehadji (1992) menyatakan bahwa umumnya peternakan rakyat di Indonesia masih berskala kecil dengan usaha sambilan dan masih menggunakan teknologi yang sangat sederhana sehingga produktivitasnya sangat rendah.

\section{Pengaruh karakteristik peternak lokal dan transmigran terhadap pendapatan}

Variabel yang diamati dalam penelitian ini adalah umur peternak, tingkat pendidikan, pengalaman peternak, keberanian mengambil resiko, curahan waktu kerja, jumlah tanggungan keluarga dan luas lahan. Hasil analisis regresi berganda pengaruh karakteristik peternak terhadap pendapatan tersaji pada Tabel 3.

Hasil analisis regresi pada Tabel 3 menunjukkan bahwa berdasarkan uji $\mathrm{F}$ secara bersama-sama variabel bebas yang diamati berpengaruh nyata $(\mathrm{P}<0,05)$ terhadap pendapatan. Nilai koefisien $\mathrm{R}^{2}$ sebesar 0,298, nilai sebesar $29,8 \%$ adalah pendapatan yang dapat dijelaskan berdasarkan variabel umur peternak, tingkat pendidikan, pengalaman peternak, keberanian mengambil resiko, curahan waktu kerja, jumlah tanggungan keluarga, luas lahan, sedangkan sisanya sebesar 70,2\% dipengaruhi oleh variabel lain yang tidak diamati pada penelitian ini. Variabel yang berpengaruh signifikan terhadap pendapatan adalah $\left(\mathrm{X}_{1}\right)$ umur peternak $(\mathrm{P}<0,05), \quad\left(\mathrm{X}_{2}\right) \quad$ tingkat pen-didikan $(\mathrm{P}<0,05),\left(\mathrm{X}_{3}\right)$ pengalaman peternak $(\mathrm{P}<0,10),\left(\mathrm{X}_{7}\right)$ kepemilikan tenak sapi $(\mathrm{P}<0,05)$ dan $(\mathrm{D})$ dummy peternak $(\mathrm{P}<0,05)$. 
Tabel 3. Hasil analisis regresi berganda pengaruh faktor karakteristik peternak lokal dan transmigran terhadap pendapatan (result of analisis regression influence of local farmers characteristic factor and transmigrant to income)

\begin{tabular}{|c|c|c|}
\hline Variabel bebas (free variable) & $\begin{array}{c}\text { Koefisien regresi } \\
\text { (regression coeficcient) }\end{array}$ & $\begin{array}{l}\text { Probabilitas } \\
\text { (probability) }\end{array}$ \\
\hline Umur peternak (tahun) (farmers age (year)) & $128926.431^{* *}$ & 0.021 \\
\hline Tingkat pendidikan (tahun) (level of education (year)) & $430394.377^{* *}$ & 0.026 \\
\hline Pengalaman peternak (tahun) (farmers experiences (year)) & $-160617.065^{*}$ & 0.050 \\
\hline Keberanian mengambil resiko (skor) (risk taking (score)) & $-628005.261^{\mathrm{ns}}$ & 0.272 \\
\hline Curahan waktu kerja (HOK) (working hour (HOK)) & $827189.294^{\mathrm{ns}}$ & 0.194 \\
\hline $\begin{array}{l}\text { Jumlah tanggungan keluarga (orang) (the number of dependents family } \\
\text { (person)) }\end{array}$ & $11960.949^{\mathrm{ns}}$ & 0.984 \\
\hline Kepemilikan ternak sapi (UT) (cattle ownership (UT)) & $631881.437^{* *}$ & 0.008 \\
\hline Luas lahan HMT $\left(\mathrm{m}^{2}\right)\left(\right.$ area of animal feed plant $\left.\left(\mathrm{m}^{2}\right)\right)$ & $-13.928^{\mathrm{ns}}$ & 0.978 \\
\hline Dummy & $4109608.801^{\text {** }}$ & 0.021 \\
\hline Konstanta ( costanta) & $-7880145.687^{*}$ & 0.096 \\
\hline
\end{tabular}

Umur peternak $\left(\mathrm{X}_{1}\right)$ berpengaruh sangat signifikan $(\mathrm{P}<0,01)$ terhadap pendapatan. Makin bertambah 1 tahun umur peternak, meningkatkan pendapatan sebesar Rp. 128.926,43. Peternak yang memiliki usia muda dan produktif akan berkerja maksimal untuk meningkatkan pendapatan.

Tingkat pendidikan $\left(\mathrm{X}_{2}\right)$ berpengaruh sangat signifikan $(\mathrm{P}<0,01)$ terhadap pendapatan. Makin bertambah 1 tahun pendidikan, meningkatkan pendapatan sebesar Rp. 430.394,38. Makin memadai pendidikan seseorang, orang tersebut semakin berpikir kreatif dan produktif dalam meningkatkan pendapatan, sebaliknya semakin rendah pendidikan orang itu akan lambat berpikir dalam meningkatkan pendapatan.

Pengalaman peternak $\left(\mathrm{X}_{1}\right)$ berpengaruh signifikan $(\mathrm{P}<0,10)$ terhadap pendapatan dengan koefisien negatif. Makin bertambah 1 tahun pengalaman peternak, mengurangi pendapatan sebesar Rp. 160.617,06 pendapatan. Makin bertambah pengalaman peternak semakin mengurangi pendapatan, seharusnya semakin bertambah pengalaman peternak semakin meningkatkan pendapatan. Dijelaskan pula bahwa pengalaman peternak cukup tinggi di Kecamatan Kairatu, namun ternyata tidak menunjukkan tatalaksana pemeliharaan sapi yang baik, mereka lebih cenderung menggunakan metode lama secara tradisional.

Kepemilikan ternak sapi $\left(\mathrm{X}_{5}\right)$ berpengaruh signifikan $(\mathrm{P}<0,05)$ terhadap pendapatan. Makin bertambah 1 unit ternak sapi potong, pendapatan meningkat sebesar Rp. 631.881,43. Makin banyak ternak yang dipelihara maka akan meningkatkan pendapatan, sebaliknya semakin sedikit jumlah pemeliharaan ternak sapi potong, maka pendapatan yang diperoleh semakin kecil. Hermanto (1996) menyatakan bahwa kepemilikan ternak berpengaruh positif terhadap pendapatan usaha tani-ternak.
Semakin banyak memelihara ternak, semakin meningkatkan pendapatan usaha tani-ternak.

Dummy peternak berpengaruh sangat signifikan $(\mathrm{P}<0,01)$ terhadap pendapatan, artinya peternak transmigran memiliki pendapatan yang lebih besar terhadap usaha sapi potong dibanding peternak lokal. Peternak yang memiliki pendapatan besar menunjukkan bahwa mereka mempunyai kesungguhan kerja pada usaha sapi potong.

Keberanian mengambil resiko $\left(\mathrm{X}_{4}\right)$ tidak berpengaruh signifikan terhadap pendapatan. Hal ini diduga karena penyampaian teknologi di lokasi penelitian belum diikuti secara keseluruhan oleh peternak, hanya sebagian kecil dari peternak yang menerima informasi tersebut sekaligus menerapkan teknologi dengan baik. Hulfa (2004) menyatakan bahwa ada beberapa faktor yang mempengaruhi berlangsungnya transformasi teknologi, diantaranya adalah faktor sosial dan faktor ekonomi peternak.

Curahan waktu kerja $\left(\mathrm{X}_{5}\right)$ berpengaruh tidak signifikan terhadap pendapatan. Hal ini diduga karena jam kerja peternak terlalu sedikit pada usaha sapi potong. Rumalutur (2001) menyatakan bahwa mereka yang memiliki sedikit waktu kerja terhadap usaha sapi potong disebut sebagai peternak sampingan.

Luas lahan HMT $\left(\mathrm{X}_{8}\right)$ berpengaruh tidak signifikan terhadap pendapatan. Hal ini diduga karena sumber daya alam yang tersedia belum dimanfaatkan peternak secara baik. Hasil penelitian Rumalutur (2001) menunjukkan bahwa umumnya peternak di Kecamatan Sentani Kabupaten Jayapura masih memberikan pakan berupa hijauan rumput atau daun-daun dari padang penggembalaan, sedangkan pemberian pakan penguat berupa konsentrat (dedak, bungkil kelapa, bungkil kacang tanah, dan jagung) jarang dilakukan peternak dengan alasan terbatasnya ekonomi keluarga. 


\section{Hubungan motivasi dengan pendapatan}

Analisis korelasi ini untuk mengetahui hubungan motivasi dengan pendapatan bagi peternak lokal dan transmigran. Hasil analisis korelasi antara motivasi dengan pendapatan tersaji pada Tabel 4.

Hasil pada Tabel 4 menunjukkan bahwa adanya hubungan positif antara motivasi $(\mathrm{P}<0,05)$ dengan pendapatan. Makin tinggi motivasi beternak, semakin tinggi pula pendapatan. Jenis peternak yang berhubungan positif $(\mathrm{P}<0,10)$ antara motivasi dengan pendapatan adalah peternak transmigran, artinya makin tinggi motivasi peternak transmigran, maka semakin besar pula pendapatan yang diperoleh, sebaliknya semakin rendah motivasi peternak transmigran semakin rendah pula pendapatan. Tingginya motivasi jika dihubungkan dengan kerja keras, tentu peternak akan memperoleh pendapatan yang sebesar-besarnya. Hasil penelitian Marnidati (2007) menunjukkan bahwa motivasi beternak kuda memiliki hubungan positif yang signifikan $(\mathrm{P}<0,01)$ dengan pendapatan.

\section{Kesimpulan dan Saran}

\section{Kesimpulan}

Berdasarkan hasil penelitian pada usaha beternak sapi potong, dapat disimpulkan bahwa: 1) terdapat perbedaan signifikan antara peternak lokal dan transmigran yakni: umur peternak, tingkat pendidikan, keberanian mengambil resiko dan curahan waktu kerja, 2) karakteristik yang signifikan terhadap motivasi adalah pengalaman peternak, tanggungan keluarga, luas lahan, dan dummy peternak, 3) karakteristik yang signifikan terhadap pendapatan adalah umur peternak, tingkat pendidikan, pengalaman peternak, kepemilikan ternak dan dummy peternak, dan 4) motivasi peternak transmigran berhubungan positif dengan pendapatan.

\section{Saran}

Diharapkan kepada peternak lokal untuk meningkatkan motivasi beternak, juga lebih serius dan berani mengambil resiko dalam usaha beternak sapi potong yang pada akhirnya memberi keuntungan pendapatan. Peternak transmigran agar lebih memperhatikan usaha ternak sapi potong dibanding usaha tani-pertanian, selain itu juga diperlukan kerjasama pemerintah (Dinas Peternakan) dalam memberikan bantuan ternak sapi potong guna pengembangan peternakan di Kecamatan Kairatu, Kabupaten Seram Bagian Barat.

\section{Daftar Pustaka}

Ahmadi, A.H. 2003. Sosiologi Pendidikan. Penerbit PT. Rineka Cipta, Jakarta.

Anggorodi. 1998. Kemajuan Mutahir dalam Ilmu Ternak Unggas. Gramedia, Jakarta.

Asnawi, S. 2007. Teori Motivasi: dalam Pendekatan Psikologi Industri dan Organisasi. Cetakan ke-3. Studia Press, Jakarta.

BPS Maluku. 2009. Seram Bagian Barat dalam Angka, Badan Pusat Statistik Maluku, Ambon.

Fathoni, A.H. 2004. Manajemen Sumber Daya Manusia. PT. Rineka Cipta, Jakarta.

Gudjarati, D.N. 2003. Basic Econometrics. Mc. Grow Hill, Singapura.

Handoko, M. 2006. Motivasi: Daya Penggerak Tingkah Laku. Kanisus, Yogyakarta.

Hermanto, F. 1996. Ilmu Usahatani. Penebar Swadaya, Jakarta.

Hulfa. 2004. Adopsi teknologi produksi sapi potong sistem kandang kelompok di Kabupaten Aceh Tengah. Tesis Pascasarjana, Universitas Gadjah Mada, Yogyakarta.

Maitimu, E. 2000. Studi mengenai struktur populasi ternak di Kecamatan Taniwel, Kabupaten Maluku Tengah. Skripsi. Universitas Pattimura, Ambon.

Mardalis. 2007. Metode Penelitian Suatu Pendekatan Proposal. PT. Bumi Aksara, Jakarta.

Marnidati, S. 2007. Motivasi dan pendapatan beternak kuda di kawasan wisata Pantai Parangtritis. Skripsi Fakultas Peternakan, Universitas Gadjah Mada, Yogyakarta.

Rumalutur, T. 2001. Peningkatan Pendapatan Keluarga Petani Transmigran dan Petani Penduduk Asli di Desa Sabron Dosay Kecamatan Sentani Kabupaten Jayapura.

Tabel 4. Hubungan motivasi dengan pendapatan (correlation the motivation and income)

\begin{tabular}{lcc}
\hline \hline \multicolumn{1}{c}{ Responden (respondent) } & $\begin{array}{c}\text { Koefisien korelasi }(\mathrm{r}) \\
(\text { coefficient correlation }(r))\end{array}$ & $\begin{array}{c}\text { Probabilitas } \\
(\text { probability })\end{array}$ \\
\hline Peternak lokal (local farmers) & $-0.029^{\text {ns }}$ & 0.420 \\
Peternak transmigran $($ transmigrant farmers $)$ & $0.237^{*}$ & 0.054 \\
\hline Total & $0.289^{* * *}$ & 0.002 \\
${ }^{\mathrm{ns}}$ non significant, $*(\mathrm{P}<0,10),{ }^{* *}(\mathrm{P}<0,05)$. & &
\end{tabular}


Universitas Cenderawasi. Available at http://www.itb.centrallibrary.ca.id. Accession date: September 2001.

Sani, A.L. 2008. Curahan tenaga kerja keluarga transmigran dan lokal pada pemeliharaan sapi potong di Kabupaten Konawe Selatan Propinsi Sulawesi Tenggara. Tesis Pascasarjana Universitas Gadjah Mada, Yogyakarta.

Sarwono, S.W. 2001. Psikologi Sosial. Balai Pustaka, Jakarta.

Singarimbun, M. dan Effendy. 1995. Metode Penelitian Survei. LP3ES, Jakarta.

Siregar, S.B. 1997. Penggemukan Sapi Potong. Edisi ke-3. Penebar Swadaya, Jakarta.

Siregar, A.S. 2009. Analisis pendapatan beternak sapi potong di Kecamatan Stabat, Kabupaten
Langkat. Skripsi. Fakultas Pertanian Universitas Sumatra Utara, Medan.

Soehadji. 1992. Alternatif pengembangan peternakan rakyat yang berwawasan pasar dalam era kebangkitan Indonesia II. Makalah Pada Temu Ilmiah Mahasiswa Peternakan Malang, Malang.

Soekartawi, A. Soeharjo, J.L. Dillon, dan J.B. Hardacker. 1986. Ilmu Usahatani dan Penelitian untuk Pengembangan Petani Kecil. Universitas Indonesia, Jakarta.

Suparno. 1994. Pendekatan Sosiologis dalam Penelitian. Available at http/www.sumbawa news.com. Accession date: 12 Maret 2011.

Tarmidi, L.T. 1992. Ekonomi Pembangunan. Penelitian Antara Universitas Studi Ekonomi, Universitas Indonesia, Jakarta. 